\title{
HARMONIC ANALYSIS OF THE WIND-LOADED BAR DOME AT THE SATELLITE SERVICES CENTRE IN PSARY
}

\author{
W. SZANIEC ${ }^{1}$, K. ZIELIŃSKA ${ }^{2}$
}

\begin{abstract}
The research paper presents the results of the dynamic analysis of an existing bar dome subjected to wind loads. The calculation model of the structure was constructed using the finite element method. The dome was subjected to the standard wind pressure, assuming that it is operates in a harmonic manner. The numerical analyses were performed with the application of Autodesk Robot and MES3D. The analysis focused on the impact of selected factors such as the frequency of forcing, wind gustiness coefficient and structural damping on the behaviour of structures.
\end{abstract}

Key words: wind load, harmonic analysis, resonance, natural vibrations, forced vibrations.

\section{INTRODUCTION}

Domes have been used as coverings of functional buildings for a long time. They usually took the form of continuous structures and were made from reed, stone blocks or wedge-shaped bricks [3]. Domes can be classified according to several criteria. As far as the type of frame is concerned, one can distinguish a bar dome, widely applied in construction industry. Bar domes flourished in the 19th century, which was connected with widely comprehended advances in engineering, the development of computational tools and the demand for such objects [4].Structures of this type cover relatively large spans, have relatively small cross dimensions of components and high lightweightness of the whole. Their drawback is, however, low stiffness in the direction normal to

\footnotetext{
' PhD., Kielce University of Technology, Faculty of Civil and Architecture Engineering, Al. 1000-lecia PP 7, 25-314 Kielce, Poland, e-mail: wszaniec@tu.kielce.pl

${ }^{2}$ MSc., Kielce University of Technology, Faculty of Civil and Architecture Engineering, Al. 1000-lecia PP 7, 25-314

Kielce, Poland, e-mail: kb88@op.pl
} 
the surface and the associated high susceptibility to weather conditions, particularly wind [7,8]. As a rule this load is highly varied in time and largely random, which makes it considerably difficult to take it into account in calculations. In designing this type of structure the geometry and position of the object together with the site characteristics provide the foundation for adopting the load in the form of the wind pressure on the structure, and on this basis static calculations are performed [5]. Such an approach does not always appear to be justified, sometimes it is advisable to perform dynamic analysis [6]. Occasionally, with low exciting forces which are sometimes hardly noticeable (weak wind gusts, the circular motion), there is a danger of resonance, both of the whole structure and of individual components. There is a number of different more or less complex models of wind load. One of the simpler ones involves presenting it as the product of the static friction $Q_{0}$ and the function $f(t)$ changing this value in time (1.1) [1]. It may be e.g. a function taking an explicit or tabular form, where the time values of load coefficients are obtained on the basis of measurements.

$$
Q(t)=Q_{0} \cdot f(t)
$$

This form of the dynamic load can be easily taken into account in the computational tools, and with a relatively small effort allows obtaining a lot of information about the effects of the impact on the structure.

\section{THE STRUCTURE AND THE CALCULATION MODEL}

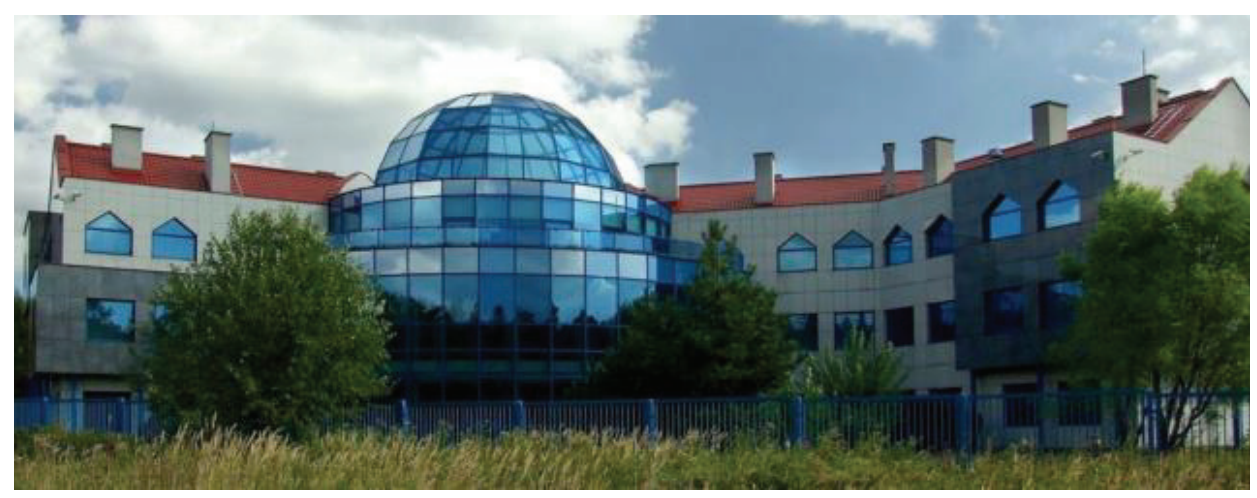

Fig. 1. General view of the CUS building in Psary 
The analysis discussed the dome of the SSC (Satellite Services Centre) in Psary. The structure in the shape of a circular hemisphere rests on a reinforced concrete roof plate, spans 12 metres and has the height of 6 metres. The load bearing structure is composed of 24 longitudinal supporting members made from RP120x60x4 profiles connected to 2L60x60x6 latitudinal members by means of rigid joints. The covering consists of the inner Optifloat pane, the PVB foil and the outer Activ Blue pane.

The dome was modelled in the Autodesk Robot programme as a spatial frame. The structure was made up of 144 nodes and 280 elements. The weight of the covering was taken into account in the model, increasing the weight of individual members. It was assumed that the dome is supported in the nodes in an articulated manner. Further dynamic analyses were performed in the authors' programme MES3D. The data were converted, they are similarly structured in both programmes, and their accuracy was checked through a comparative modal analysis.
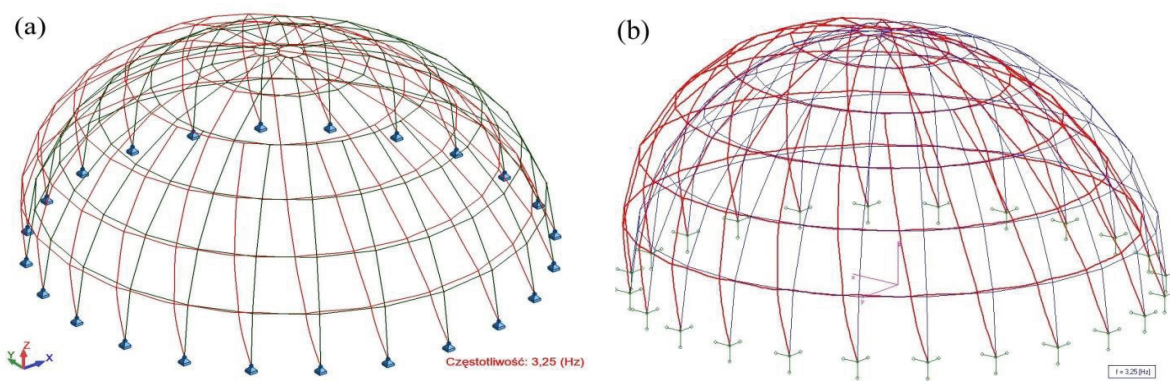

Fig.2. The first form of normal modes a) MES3D b) Robot

The dome was subjected to a standard wind pressure (fig. 3). The static wind load was adopted on the basis of the Polish standard PN-EN 1991-1-4:2008 [4,9].
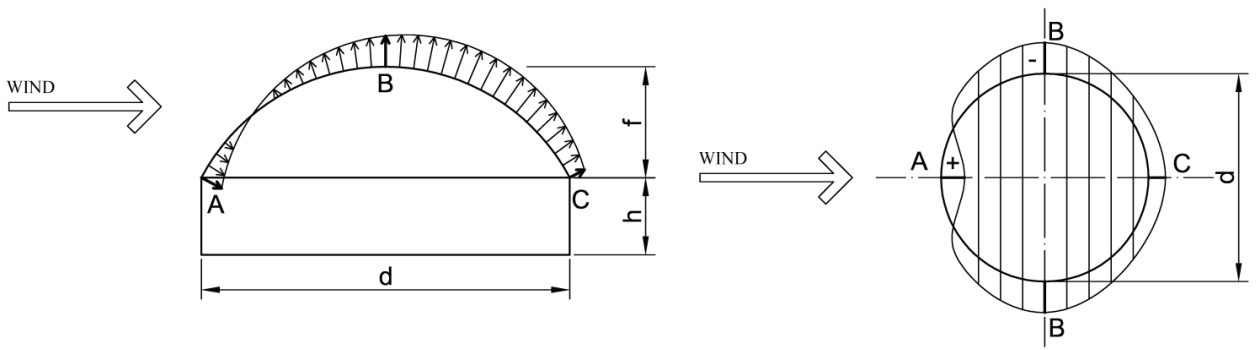

Cpe, $10=$ constant at every level

Fig.3. Distribution of standard wind pressure of circular dome [3] 
It was assumed that its direction coincides with the vibration direction of the first own form. The object is situated in the first wind load zone. The values of the external pressure coefficient assumed in points $\mathrm{A}, \mathrm{B}, \mathrm{C}$ were equal to $C_{p e, 10}=0.8 ;-1.3 ;-0.5$, respectively [2].

The calculated wind pressure, acting in the direction normal to the dome surface, was reduced to a distributed load applied to individual latitudinal members and then to the system of concentrated forces in the adjacent nodes. The adopted load diagram is shown in Fig. 4.

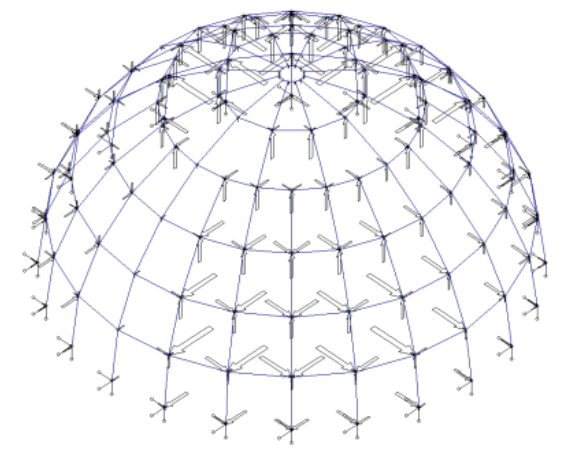

Fig. 4. Wind load reduced to concentrated forces- MES3D

The structure's response to the harmonic-type excitement was analyzed. Two load models were examined. In the first one it is a static load modulated with wind gusts, which takes the following form:

$$
Q(t)=P_{0}\left[1+p \cdot \sin \left(n_{0} \cdot t\right)\right]
$$

where:

$P_{0}-$ static wind load, $p$ - wind gustiness coefficient and $n_{0}-$ frequency of forcing.

In the second one it is a single pulse with the duration time $T$ and it is represented by the formula:

$$
Q(t)=P_{0} \cdot \sin (\pi \cdot T)
$$

where

$T$-duration time of a single impulse 
Due to the reliability analysis, which will be performed in the next stage of the procedure, as well as the lack of real wind characteristics for this object, a fairly wide range of load parameters was assumed. The objective of the conducted analysis was to observe dangerous states in the discussed bar dome.

The dynamic equilibrium equation of the system has the following form:

$$
K_{S} \cdot \bar{q}_{S}+R_{S} \cdot \dot{\bar{q}}_{S}+B_{S} \cdot \ddot{\bar{q}}_{S}=\bar{F}_{S}(Q(t))
$$

where:

$B_{S}, R_{S}, K_{S}$ - inertia, damping and structure stiffness matrices, $\bar{F}_{S}$ - load balancers vector which is a load function, $\overline{q_{s}}(t), \dot{\overline{q_{s}}}(t), \ddot{\overline{q_{s}}}(t)$ - coordinates, velocity and general acceleration vectors.

The set of equations (3.3) was solved with Newmark method using an unconditionally stable variant. The performed calculations took the damping into account or disregarded it. A model was adopted in which it is proportionate to the rigidity of the system $\left(R_{S}=\kappa \cdot K_{S}, \kappa=0.005\right)$. For the first load the length of the time step was adopted as $\Delta t=0.001[s]$ and the total calculation time $T=40[s]$. The parameter $p$, modeling the wind gustiness was equal to 0.1 and 0.3 , and the frequency of the harmonic excitement $n_{0}$ was adopted in the range of $0.1 \div 1$ value of the first frequency of natural vibrations $\left(\mathrm{n}_{0}=0.1 \div 1 \cdot \omega_{1}\right)$. In the second variant the pulse duration time was adopted within the range of $0.5-2[\mathrm{~s}]$ and the basic wind speed as $v_{b}=22,30,40$ and $50[\mathrm{~m} / \mathrm{s}]$

\section{RESUltS ANALYSIS}

The displacements and accelerations of the selected points of the structure were analyzed. The first measurement point was assumed in the highest node of the meridian on the symmetry axis of the first form of natural vibrations, followed by the reading of the values of vertical displacements and accelerations.

Point 2 was located in the middle of its length with horizontal values being analysed here. Table 1 shows the values of the displacements and accelerations of individual points, obtained from a harmonic analysis taking into account damping as well as the static solutions. 
Table. 1. Displacements and dislocations of points 1 and 2 with $n_{0}=0.2 \div 1.0$

\begin{tabular}{|c|c|c|c|c|c|c|}
\hline & statics & $n_{0}=0.2$ & $n_{0}=0.4$ & $n_{0}=0.6$ & $n_{0}=0.8$ & $n_{0}=1.0$ \\
\hline \multicolumn{7}{|c|}{$\mathrm{p}=0.1$} \\
\hline $\max q_{1 z}$ & 0.59 & 0.79 & 0.83 & 0.87 & 1.06 & 2.28 \\
\hline $\max q_{2 y}$ & 17.71 & 17.77 & 18.55 & 19.30 & 22.52 & 43.58 \\
\hline $\max a_{l z}$ & - & 0.00 & 0.01 & 0.01 & 0.03 & 0.19 \\
\hline $\max a_{2 y}$ & - & 0.04 & 0.11 & 0.25 & 0.60 & 3.31 \\
\hline \multicolumn{7}{|c|}{$\mathrm{p}=0.3$} \\
\hline $\max q_{1 z}$ & 0.70 & 0,92 & 1,04 & 1,16 & 1,70 & 5,39 \\
\hline $\max q_{2 y}$ & 20.91 & 21,16 & 23,52 & 25,77 & 35,38 & 98,60 \\
\hline $\max a_{1 z}$ & - & 0,01 & 0,02 & 0,04 & 0,09 & 0,56 \\
\hline $\max a_{2 y}$ & - & 0,12 & 0,34 & 0,74 & 1,81 & 9,94 \\
\hline
\end{tabular}

Fig. 5-9 present examples of dynamic waveforms based on the calculations for this load.

Fig. 5 and 6 present the displacement graphs for points 1 and 2 with $p=0.1$ and 0.3 and the excitement frequency of $n_{0}=0.9 \cdot \omega_{1}$, either taking the damping into account or disregarding it.

Fig. 7-9 present the acceleration variability graphs for these points with $p=0.1$ and 0.3 and $n_{0}=0.9 \cdot \omega_{1}$ and $1.0 \cdot \omega_{1}$.
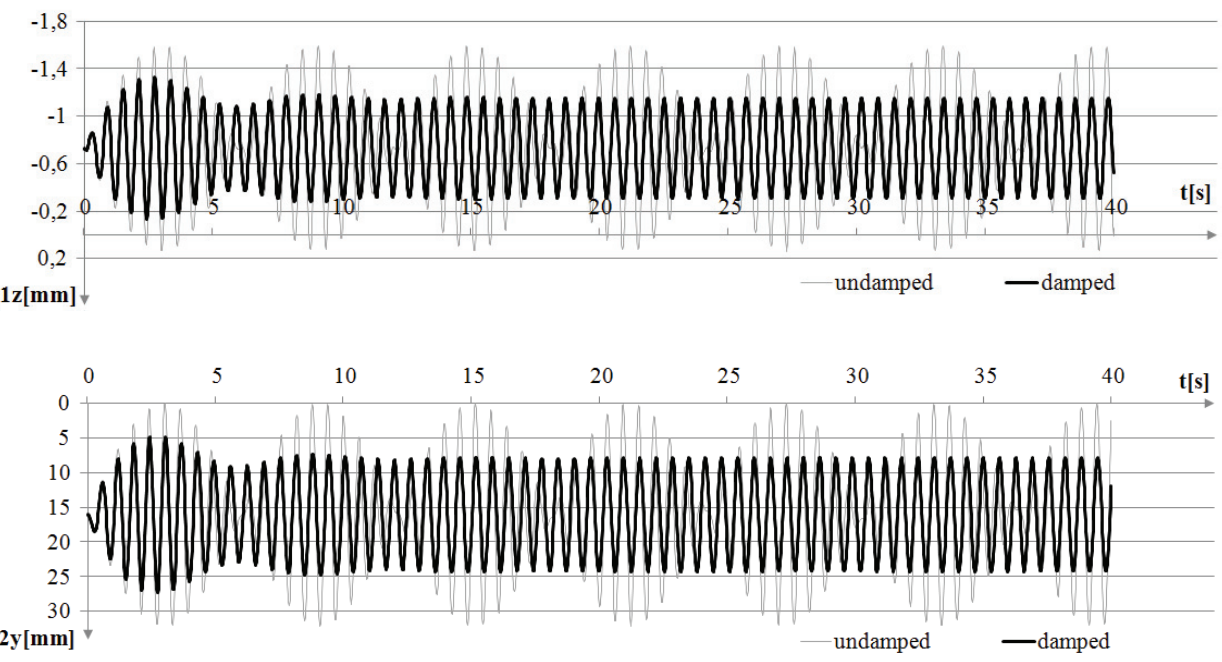

Fig.5. The graph of displacements in time for $\mathrm{p}=0.1$ and $\mathrm{n}_{0}=0.9 \cdot \omega_{1}$ for points 1 and 2 


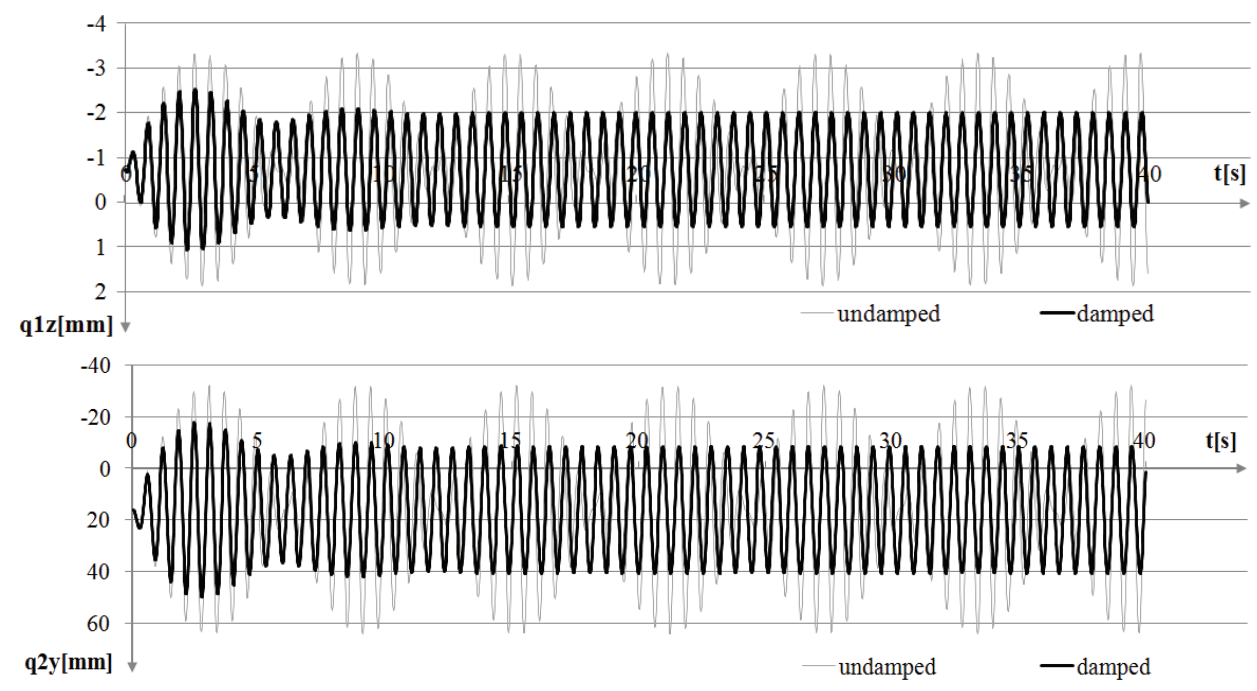

Fig.6. The graph of displacements in time for $\mathrm{p}=0.3$ and $\mathrm{n}_{0}=0.9 \cdot \omega_{1}$ for points 1 and 2 .
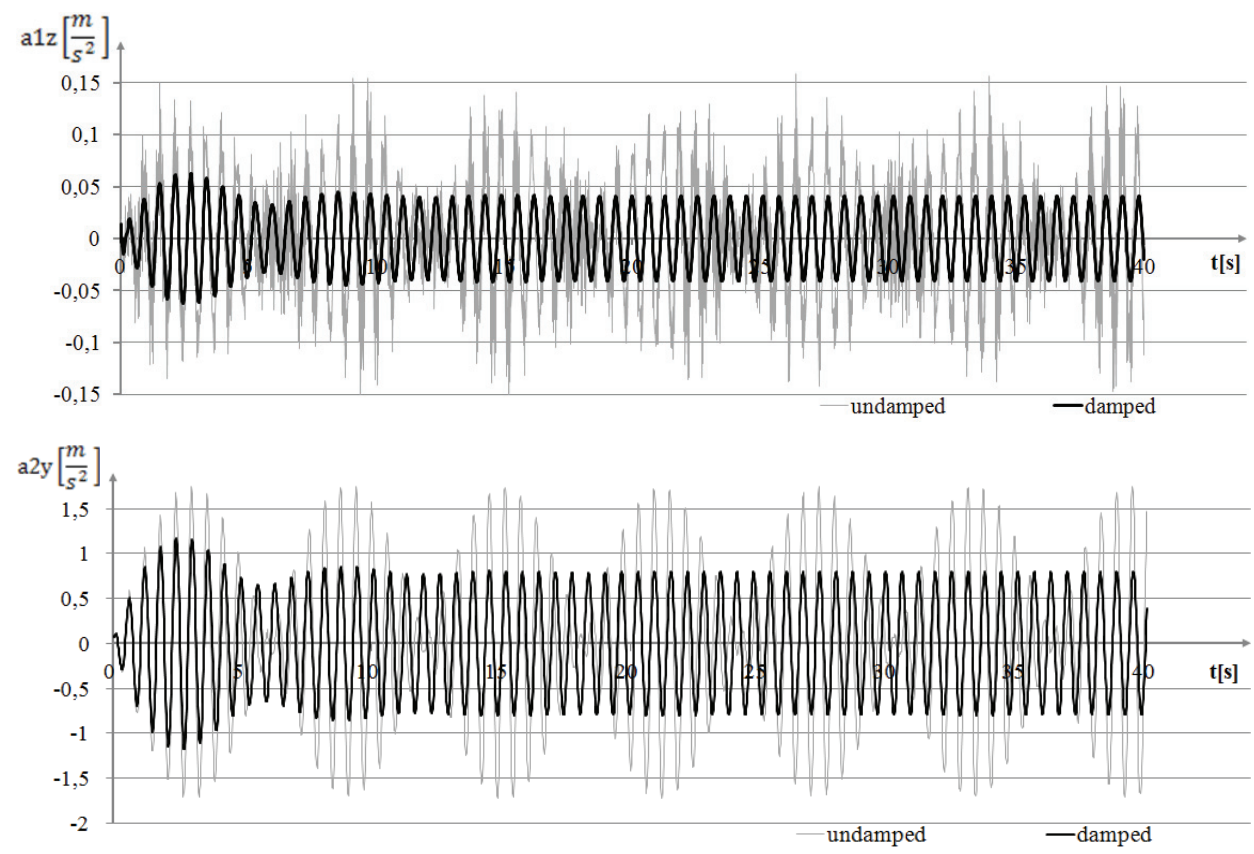

Fig.7. The graph of acceleration in time for $\mathrm{p}=0.1$ and $\mathrm{n}_{0}=0.9 \cdot \omega_{1}$ for points 1 and 2 . 


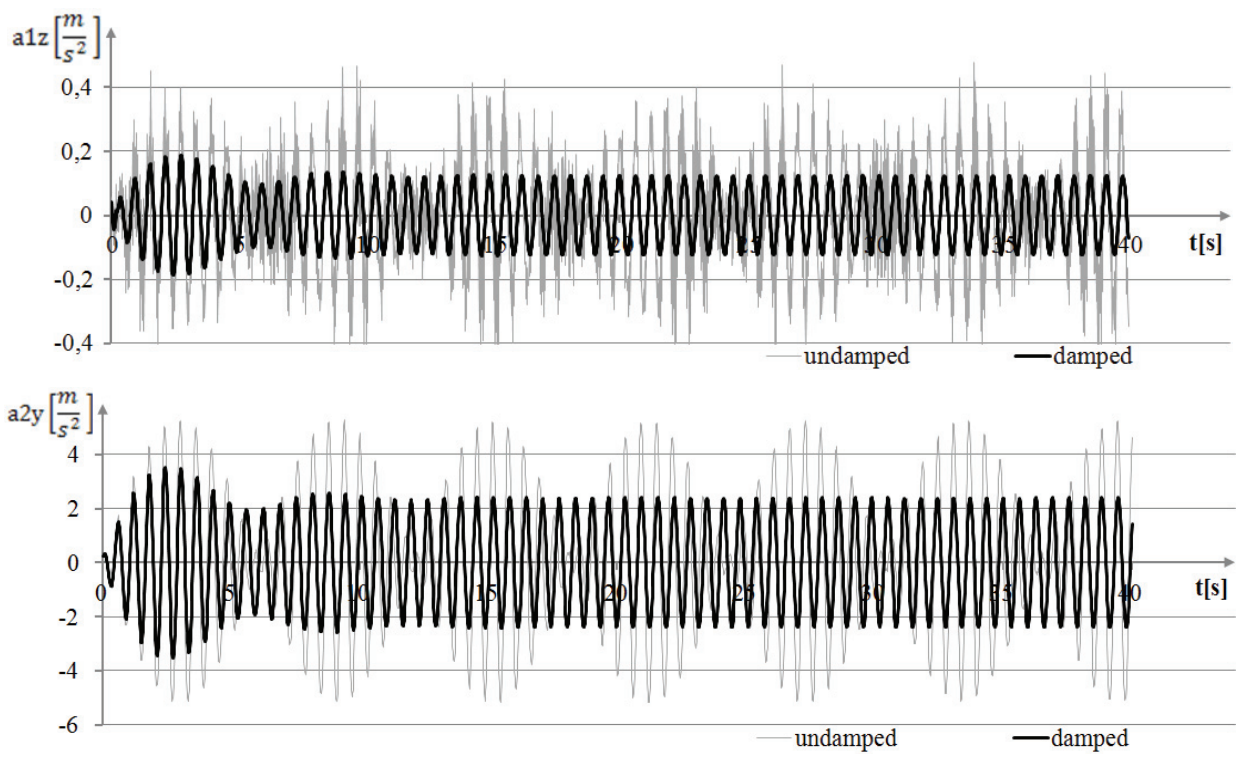

Fig.8. The graph of acceleration in time for $\mathrm{p}=0.3$ and $\mathrm{n}_{0}=0.9 \cdot \omega_{1}$ for points 1 and 2 .
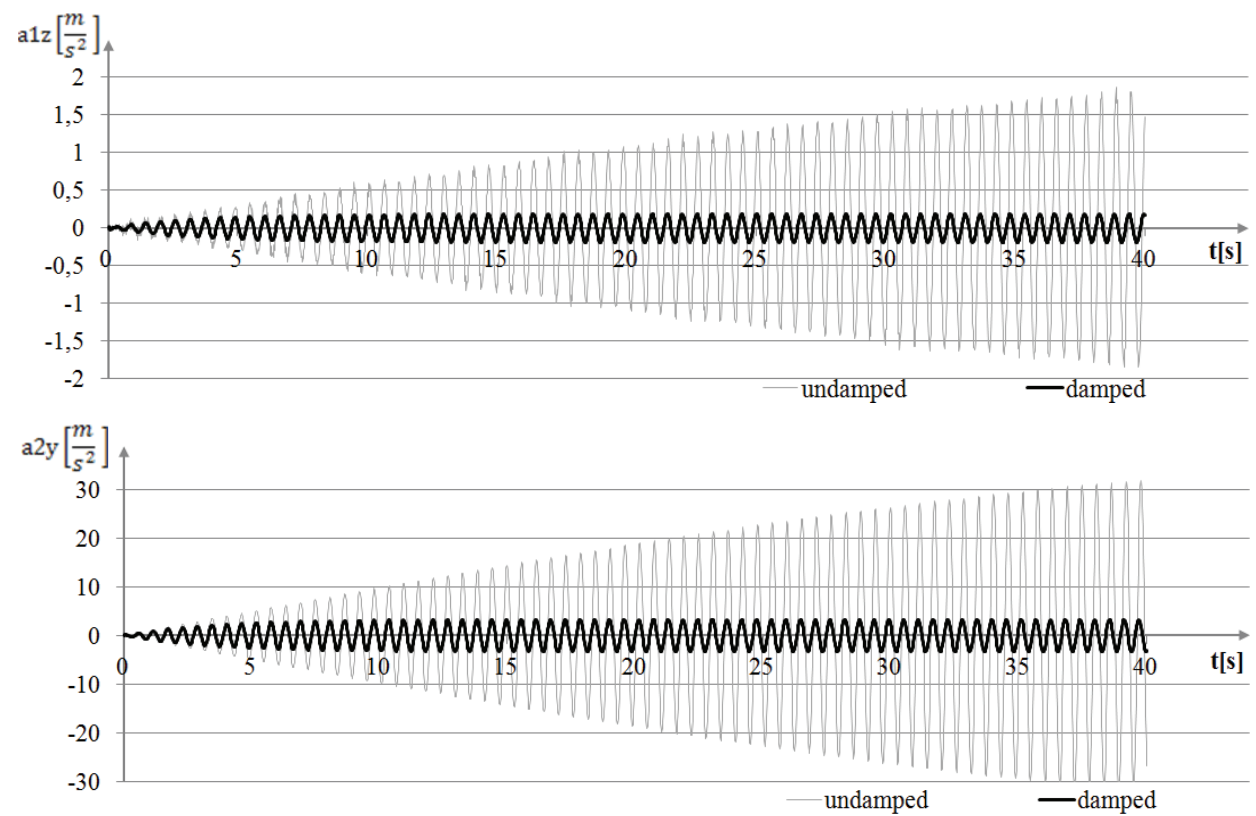

Fig.9. The graph of acceleration in time for $\mathrm{p}=0.1$ and $\mathrm{n}_{0}=1 \cdot \omega_{1}$ for points 1 and 2 . 
Fig.10 presents the graph of the relation between the vertical displacement of point 1and the forcing frequency. Fig.11 presents an analogous graph of acceleration for this point.

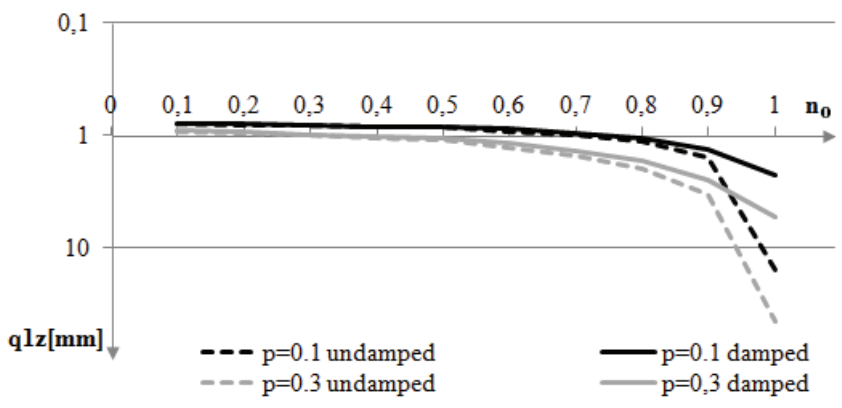

Fig. 10. The graph of the relation between the displacement and the natural vibration frequency for $\mathrm{p}=$ 0.1 and 0.3 for point 1

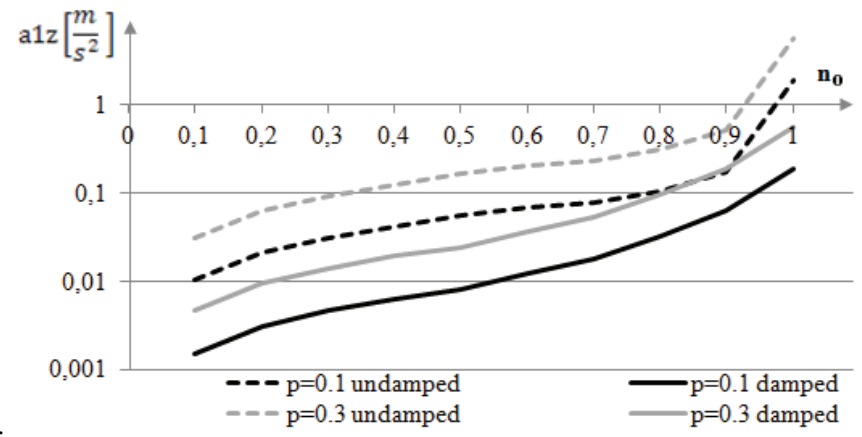

Fig. 11. The graph of the relation between the displacement and the natural vibration frequency for $\mathrm{p}=$ 0.1 and 0.3 for point 1 .

Table 2 shows the solutions obtained with different basic wind speeds. Fig. 12 presents selected dynamic waveforms obtained with the wind pulse load (3.2) with $v_{b}=22[\mathrm{~m} / \mathrm{s}]$, considering damping. Table 3 contains the solutions obtained with this load with different duration time of this pulse. Fig. 13 shows selected dynamic waveforms obtained in this analysis.

Table. 2. Displacements and dislocations of points 1 and 2 with $v_{b}=22 \div 50[\mathrm{~m} / \mathrm{s}]$

\begin{tabular}{|c|c|c|c|c|c|}
\hline & statics & $v_{b}=[22 \mathrm{~m} / \mathrm{s}]$ & $v_{b}=30[\mathrm{~m} / \mathrm{s}]$ & $v_{b}=40[\mathrm{~m} / \mathrm{s}]$ & $v_{b}=50[\mathrm{~m} / \mathrm{s}]$ \\
\hline $\max q_{l z}$ & 0.54 & 0.86 & 1.47 & 2.42 & 3.70 \\
\hline $\max q_{2 v}$ & 16.09 & 17.69 & 35.15 & 61.06 & 96.22 \\
\hline $\max a_{l z}$ & - & 0.08 & 0.09 & 0.16 & 0.24 \\
\hline $\max a_{2 y}$ & - & 0.42 & 0.57 & 1.00 & 1.57 \\
\hline
\end{tabular}


Table. 3. Displacements and dislocations of points 1 and 2 with $T=0.5 \div 1.0[s]$

\begin{tabular}{|l|c|c|c|c|c|}
\hline & statics & $T=0.5[s]$ & $T=1.0[s]$ & $T=1.5[s]$ & $T=2.0[s]$ \\
\hline $\max q_{l z}$ & 0.54 & 1.49 & 1.06 & 0.86 & 0.87 \\
\hline $\max q_{2 y}$ & 16.09 & 27.43 & 21.72 & 17.69 & 18.49 \\
\hline $\max a_{l z}$ & - & 0.25 & 0.11 & 0.08 & 0.05 \\
\hline $\max a_{2 y}$ & - & 3.04 & 0.83 & 0.42 & 0.31 \\
\hline
\end{tabular}
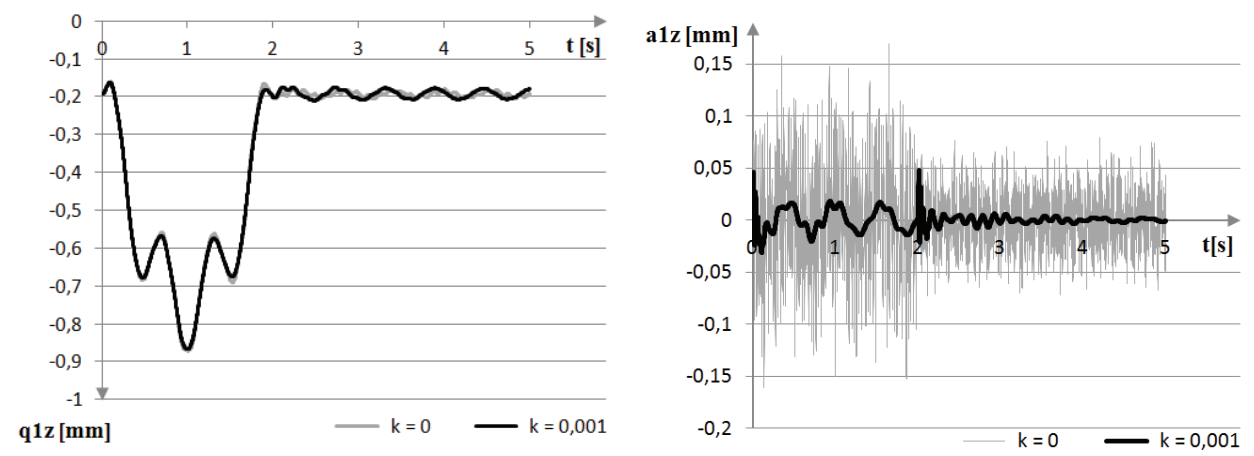

Fig. 12. Dependency graph for the displacement $\mathrm{q}_{1 \mathrm{z}}(\mathrm{t})$ and $\mathrm{a}_{1 \mathrm{z}}(\mathrm{t})$ for the wind pulse load at $v_{b}=22[\mathrm{~m} / \mathrm{s}]$
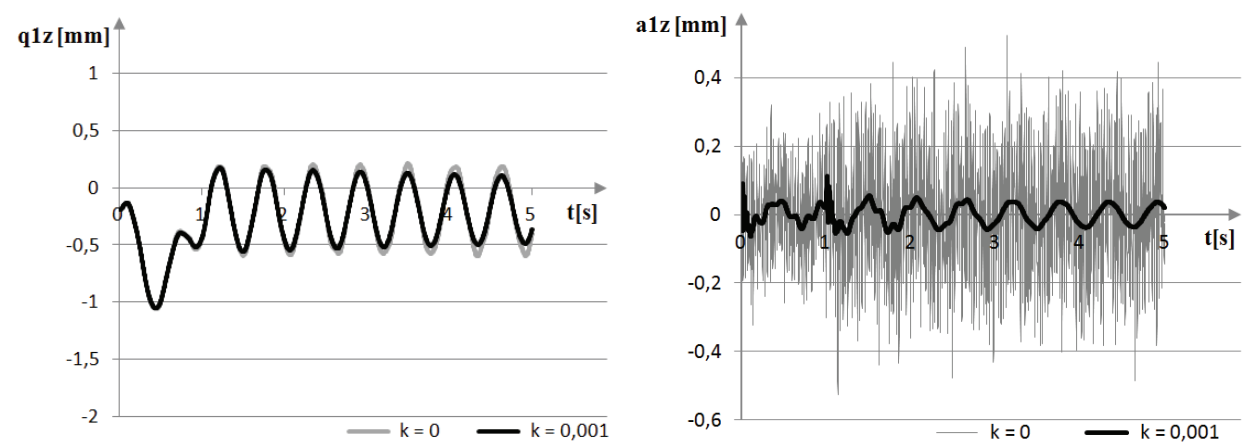

Fig. 13. Dependency graph for the displacement $\mathrm{q}_{1 \mathrm{z}}(\mathrm{t})$ and $\mathrm{a}_{1 \mathrm{z}}(\mathrm{t})$ for the wind pulse load at $T=1[s]$

\section{Conclusions}

The conducted analyses permitted the evaluation of the effect of the discussed parameters on the bahaviour of the existing bar dome. As the excitement frequency rises, both the displacement and acceleration increase exponentially (Fig. 10-11). In the case of the excitement frequency approaching the structure's natural frequency, one can observe the beat phenomenon (Fig. 5-8) or getting into resonance 
(Fig.9) and quick stabilization of the vibration amplitude when damping is taken into account (Fig.9). The effect of the coefficient $p$ which takes into account the wind gustiness, is similar to that in the static case. The obtained boundary displacement values are similar in both cases. The coefficient did not pose a major threat to the structure within the analyzed range, since the safety coefficients applied in designing an object reduce the impact of this factor. The state when the excitement frequency approaches a natural vibration frequency poses much more danger, both in the case of a short wind pulse and a load exerted for a longer time. Considerable values of the dynamic coefficient, significantly exceeding the values applied in the design of this type of objects. However, in the case of a real object this frequency is so high that the likelihood of resonance evoked by this factor seems insignificant. Damping is an additional factor that enhances the safety of the structure, considerably reducing the amplitude of vibrations, especially near the resonance zone.

\section{REFERENCES}

1. A. Ambroziak, "Dynamiczna analiza membranowego przekrycia wiszącego", Inżynieria i Budownictwo, nr $2 / 2005$

2. Norma PN-EN 1991-1-4:2008 Eurokod 1. Oddziaływania na konstrukcję. Część 1-4: Oddziaływania ogólne. Oddziaływania wiatru.

3. J. Mirski, "Geneza i morfologia kopuł pełnościennych", Kwartalnik Architektury i Urbanistyki. Tom XLVII. Zeszyt 2/2002: 126-146, Warszawa 2003.

4. Z. Kowal, "Hale o dużych rozpiętościach", Poradnik projektanta konstrukcji metalowych. T. 2. Praca zbiorowa pod kierunkiem W. Boguckiego. Arkady, Warszawa 1982.

5. J. A. Żurański, "Obciążenia wiatrem budowli i konstrukcji”, Centralny Ośrodek Badawczo- Projektowy Budownictwa Przemysłowego „Bistyp”, Arkady. Warszawa 1978.

6. J. Kawecki, "Oddziaływania dynamiczne na obiekty budowlane", Zeszyty Naukowe Politechniki Rzeszowskiej, nr 276, seria: Budownictwo i Inżynieria Środowiska, zeszyt 58, nr 3/201/I , 115-134, Rzeszów 2011.

7. R. Lewandowski, "Dynamika konstrukcji budowlanych", Politechnika Poznańska, Poznań 2006.

8. R. Lewandowski, "Redukcja drgań konstrukcji budowlanych", Wykład obieralny 2002.

9. A. Flaga, Inżynieria wiatrowa. Podstawy zastosowania. Wydawnictwo Arkady, Warszawa 2008

Received 11.09. 2015

Revised 05. 10. 2015

\section{LIST OF FIGURES AND TABLES:}

Fig. 1. General view of the CUS building in Psary.

Rys. 1. Widok ogólny budynku CUS w Psarach

Fig. 2. The first form of normal modes a) MES3D, b) Robot

Rys. 2. Pierwsza forma drgań a) MES3D, b) Robot

Fig. 3. Distribution of standard wind pressure of circular dome [3].

Rys. 3. Rozkład normowego ciśnienia wiatru kopuły kołowej [3].

Fig. 4. Wind load reduced to concentrated forces- MES3D.

Rys. 4. Obciążenie wiatrem sprowadzone do sił skupionych- MES3D. 
Fig. 5. The graph of displacements in time for $\mathrm{p}=0.1$ and $\mathrm{n}_{0}=0.9 \cdot \omega_{1}$ for points 1 and 2 .

Rys. 5. Wykres zależności przemieszczeń w czasie dla $\mathrm{p}=0.1 \mathrm{i}_{0}=0.9 \cdot \omega_{1}$ dla punktu 1 i 2 .

Fig. 6. The graph of displacements in time for $\mathrm{p}=0.3$ and $\mathrm{n}_{0}=0.9 \cdot \omega_{1}$ for points 1 and 2 .

Rys. 6. Wykres zależności przemieszczeń w czasie dla $\mathrm{p}=0.3$ i $\mathrm{n}_{0}=0.9 \cdot \omega_{1}$ dla punktu 1 i 2 .

Fig. 7. The graph of acceleration in time for $\mathrm{p}=0.1$ and $\mathrm{n}_{0}=0.9 \cdot \omega_{1}$ for points 1 and 2 .

Rys. 7. Wykres zależności przyspieszenia w czasie dla $\mathrm{p}=0.1 \mathrm{i}_{0}=0.9 \cdot \omega_{1}$ dla punktu 1 i 2 .

Fig. 8. The graph of acceleration in time for $\mathrm{p}=0.3$ and $\mathrm{n}_{0}=0.9 \cdot \omega_{1}$ for points 1 and 2 .

Rys. 8. Wykres zależności przyspieszenia w czasie dla $\mathrm{p}=0.3 \mathrm{i}_{0}=0.9 \cdot \omega_{1}$ dla punktu 1 i 2 .

Fig. 9. The graph of acceleration in time for $p=0.1$ and $n_{0}=1 \cdot \omega_{1}$ for points 1 and 2 .

Rys. 9. Wykres zależności przyspieszenia w czasie dla $\mathrm{p}=0.1 \mathrm{i}_{0}=1 \cdot \omega_{1}$ dla punktu 1 i 2.

Fig. 10. The graph of the relation between the displacement and the natural vibration frequency for $\mathrm{p}=$ 0.1 and 0.3 for point 1 .

Rys. 10. Wykres zależności przemieszczenia od częstości drgań własnych dla $\mathrm{p}=0.1$ i 0.3 dla punktu 1 .

Fig. 11. The graph of the relation between the acceleration and the natural vibration frequency for $p=$ 0.1 and 0.3 for point 1 .

Rys. 11. Wykres zależności przyspieszenia od częstości drgań własnych dla $\mathrm{p}=0.1$ i 0.3 dla punktu 1 .

Fig. 12. Dependency graph for the displacement $\mathrm{q} 1 \mathrm{z}(\mathrm{t})$ and $\mathrm{a} 1 \mathrm{z}(\mathrm{t})$ for the wind pulse load at $v_{b}=22 \mathrm{~m} / \mathrm{s}$ Rys. 12. Wykres zależności przemieszczenia $\mathrm{q} 1 \mathrm{z}(\mathrm{t})$ i alz(t) dla obciążenia impulsem wiatru przy $v_{b}=22 \mathrm{~m} / \mathrm{s}$

Fig. 13. Dependency graph for the displacement $\mathrm{q} 1 \mathrm{z}(\mathrm{t})$ and $\mathrm{alz}(\mathrm{t})$ for the wind pulse load at $T=1[s]$

Rys. 13. Wykres zależności przemieszczenia q1z(t) i alz(t) dla impulsem wiatru przy $T=1[s]$

Tab. 1. Displacements and dislocations of points 1 and 2 with $n_{0}=0.2 \div 1.0$

Tab. 1. Wartości przemieszczeń i przyspieszeń punktów 1 i 2 przy no $=0.2 \div 1.0$

Tab. 2. Displacements and dislocations of points 1 and 2 with $\mathrm{v}_{\mathrm{b}}=22 \div 50 \mathrm{~m} / \mathrm{s}$

Tab. 2. Wartości przemieszczeń i przyspieszeń punktów 1 i 2 przy $\mathrm{v}_{\mathrm{b}}=22 \div 50 \mathrm{~m} / \mathrm{s}$

Tab. 3. Displacements and dislocations of points 1 and 2 with $T=0.5 \div 1.0[s]$

Tab. 3. Wartości przemieszczeń i przyspieszeń punktów 1 i 2 przy $\mathrm{T}=0.5 \div 1.0 \mathrm{~s}$ 


\section{ANALIZA HARMONICZNA KOPULY PRĘTOWEJ CENTRUM USLUG SATELITARNYCH W PSARACH OBCIĄŻONEJ WIATREM}

Slowa kluczowe: obciążenie wiatrem, analiza harmoniczna, rezonans, drgania własne, drgania wymuszone.

\section{STRESZCZENIE:}

Kopuły prętowe to obiekty inżynierskie charakteryzujące się dużymi rozmiarami przy stosunkowo niewielkich przekrojach elementów i jednocześnie dużej lekkości całej konstrukcji. Ustroje te, ze wzglądu na swoją małą sztywność, są wrażliwe na działanie czynników atmosferycznych, w szczególności wiatru. Obciążenie to charakteryzuje się dużą zmiennością, jest w znacznym stopniu czynnikiem losowym, co w sposób istotny utrudnia wykonywanie obliczeń. W przypadku projektowania takich obiektów, na podstawie geometrii obiektu, położenia i charakterystyki terenu przyjmuje się obciążenie w postaci parcia wiatru i na tej podstawie wykonuje obliczenia statyczne. W przypadku rozpatrywanych konstrukcji takie podejście nie zawsze wydaje się uzasadnione, niekiedy wskazane jest wykonywanie analiz dynamicznych. Nawet przy niewielkich siłach wymuszających, czasem trudno zauważalnych, istnieje niebezpieczeństwo wystąpienia zjawiska rezonansu, zarówno całej konstrukcji, jak i jej poszczególnych elementów.

Obciążenie wiatrem może być przedstawione jako iloczyn statycznego parcia wiatru oraz funkcji zmieniającej tę wartość w czasie. W pracy przyjęto ją w postaci harmonicznej. Ze względu na brak rzeczywistych charakterystyk wiatrowych przyjęto dość szeroki zakres parametrów opisujących to obciążenie (częstość wymuszenia, współczynniki porywistości, prędkość bazowa).

Analizowano kopułę Centrum Usług Satelitarnych w Psarach. Konstrukcja ma 12m rozpiętości, 6m wysokości i opiera się na żelbetowej płycie stropu. Przekrycie jest w postaci kopuły prętowej jednowarstwowej o rzucie koła. Układ nośny zbudowany jest z 24 południkowych elementów wsporczych sztywno połączonych z elementami równoleżnikowymi. Przekrycie obiektu stanowi: szyba wewnętrzna Optifloat, folia PVB oraz szyba zewnętrzna Activ Blue.

W programie Autodesk Robot zbudowano model obliczeniowy konstrukcji metody elementów skończonych. Wykorzystano w nim elementy ramy przestrzennej o sześciu stopniach swobody w węźle. Układ liczył 144 węzły i 280 elementów. W modelu uwzględniono masę przekrycia zwiększając ciężar poszczególnych elementów ramowych. Przyjęto, że kopuła jest podparta w węzłach w sposób przegubowy.

Ze względu na dalsze analizy niezawodnościowe, właściwe obliczenia zostały wykonane w autorskim programie MES3D. W tym celu wykonano konwersję danych oraz sprawdzono ich poprawność wykonując testy statyczne i analizę modalną.

Obciążenie wiatrem przyjęto na podstawie polskiej normy PN-EN 1991-1-4:2008. Obiekt leży w I strefie obciążenia. Kierunek wiatru pokrywał się z głównym kierunkiem drgań pierwszej formy własnej. Obliczone parcie normowe zastąpiono układem sił skupionych działających w węzłach kopuły. Przyjęto, że obciążenie to działa w sposób harmoniczny. W pierwszym modelu było przedstawione jako parcie statyczne modulowane podmuchami, opisanymi funkcją sinusową, w drugim miało charakter pojedynczego impulsu działającego przez okres $T$.

Do rozwiązywania układu równań różniczkowych MES wykorzystano metodę Newmarka, wariant bezwarunkowo stabilny. Badano wpływ wybranych czynników na zachowanie się wybranych punktów konstrukcji nośnej. Pierwszy z nich przyjęto w najwyższym węźle południka na kierunku osi symetrii pierwszej formy drgań własnych (w zworniku), drugi w połowie jego długości. W pracy zamieszczono wybrane przebiegi dynamiczne uzyskane w trakcie obliczeń. 
W przypadku pierwszego modelu obciążenia badano wpływ częstości wymuszenia, współczynnika porywistości oraz thumienia na rozwiązania. Wyniki zestawiono w tabeli 1. Dla poszczególnych punktów przedstawiono wykresy przemieszczeń i przyspieszeń przy współczynniku porywistości równym 0.1 i 0.3 (10 oraz 30\% statycznej wartości obciążenia) oraz częstości wymuszenia równej 0.9 i 1.0 wartości pierwszej częstości drgań własnych, z uwzględnieniem oraz bez thumienia.

Dla obciążenia w postaci silnego podmuchu analizowano wpływ prędkości bazowej oraz czas trwania impulsu wiatru na dynamiczną pracę konstrukcji. Uzyskane rozwiązania pokazano w tablicach 2 i 3 oraz na oscylogramach.

Przeprowadzone obliczenia pozwoliły ocenić wpływ analizowanych parametrów na zachowanie się istniejącej kopuły prętowej. Wraz ze wzrostem częstości wymuszenia zarówno przemieszczenia, jak i przyspieszenia wzrastają w sposób wykładniczy. W przypadku częstości wymuszenia w pobliżu częstości własnej konstrukcji można zaobserwować zjawisko dudnienia lub przechodzenie w stan rezonansu oraz szybkie stabilizowanie się amplitudy drgań w przypadku uwzględnienia tłumienia. Wpływ porywistości wiatru jest podobny jak w zagadnieniu statycznym, uzyskane graniczne wartości przemieszczeń w obydwu przypadkach są na podobnym poziomie. W rozpatrywanym zakresie nie stanowił on większego zagrożenia dla konstrukcji, współczynniki bezpieczeństwa wykorzystywane przy projektowaniu obiektu, niwelują wpływ tego czynnika. Znacznie większe niebezpieczeństwo tkwi w przypadku wymuszenia na poziomie zbliżonym do którejś z częstości drgań własnych, zarówno w przypadku krótkiego impulsu wiatru, jak i obciążenia działającego przez dłuższy czas. Otrzymane tu wartości współczynnika dynamicznego znacznie przewyższają wielkości stosowane przy projektowaniu tego typu obiektów. Parametry tego obciążenia znacznie jednak odbiegają od rzeczywistych i prawdopodobieństwo wystąpienia rezonansu wydaje się być znikome. Czynnikiem, który w sposób istotny wpływa na uzyskiwane rozwiązania jest tłumienie, pomijanie go może prowadzić do powstawania dużych błędów obliczeniowych. 